The port-city relationships in two European inland ports: a geographical perspective on urban governance

Jean Debrie ${ }^{1}$

Paris 1 Panthéon-Sorbonne University, Paris, France

Nicolas Raimbault ${ }^{2}$

Paris East University, Marne-la-Vallée, France

${ }^{1}$ UMR Géographie-cités, University Paris 1 Panthéon-Sorbonne, Paris, France 13 rue du Four, 75006 Paris, France, E-mail: jean.debrie@univ-paris1.fr

${ }^{2}$ SPLOTT-IFSTTAR, University Paris East, Marne-la-Vallée, France

Cité Descartes, Champ-sur-Marne, 77455 Marne-la-Vallée cedex 2. E-mail: nicolas.raimbault@ifsttar.fr

Corresponding author:

Jean Debrie, UMR Géographie-cités, 13 rue du Four, 75006 Paris, France.

Email: jean.debrie@,univ-paris1.fr 


\title{
The port-city relationships in two European inland ports: a geographical perspective on urban governance
}

\begin{abstract}
Urban development projects involve some complex relationships between institutional public agents, who govern local territories, and economic agents, who make urban economies. These relationships between the stakeholders of the economic sectors (transport, water, housing, energy, industry...) and the territories shaped by public action thus define the type of urban governance which results from interactions. In this paper, we develop the hypothesis that the relation between these stakeholders has a major impact on the mechanisms that produce the city. In this perspective, we apply an analytical framework (sector/territory dialogues) to two river cities in order to understand how the interplay between the stakeholders modifies urban geography. Analysing the relationship between the city, the river and the port in Venlo (the Netherlands) and Strasbourg (France) provides examples of project-based urban planning that is founded on negotiation between the river stakeholders (port authorities, inland waterway managers, transport and logistics firms) and the different levels of public policies (municipal, intermunicipal, regional, national levels). Eventually, this approach allows us to consider the forms taken by the above sector-territory dialogue within the urban space in terms of tools and scales. Finally, the paper ends with a discussion about the value of a contribution from geography to an understanding of these governance issues.
\end{abstract}

Keywords Port-city relationship, urban projects, inland port, governance

\section{Introduction: the geography of governance and urban projects}

Many scholars have drawn attention, in an academic context, to the introduction of project-based urban planning in metropolises (Pinson, 2009, Graham and Marvin, 2001, Fainstein, 2004, Douglas and Huang, 2007, Young and Keil, 2010) which is linked to an entrepreneurial approach to urban governance (Harvey, 1989, Brenner and Theodore, 2002, Macleod, 2011). Urban projects represent a break with a conception of urban planning that is based on a linear planning approach, as they are part of a permanent dialectic between the creation of a project for the territory in question, which lays down the major principles and the overall vision, and specific urban development projects (UDP). Urban projects thus lead to an increase in the number and diversity of the public and private sector stakeholders involved in implementing local and regional public policies. The political sphere gains a vital coordinating role but loses the monopoly of legitimacy with regard to defining a project and the interests of the territory. Urban projects are this way a means of mobilizing a variety of players and resources and a means of deciding on the shared interests of a territory (Pinson, 2004).

Analysing UDP thus allows us to examine the relationships between the private and public sector stakeholders responsible for producing the city. The aim of this paper is to make a methodological contribution to the analysis of urban projects by proposing a 
geographical interpretation of the interplay between stakeholders in order to identify their impacts on urban form (Graham and Marvin, 2001, McKenzie, 2006).

Initially, we will propose an interpretation of this geography of urban governance which is defined by the interplay between sectors and territories (Part 1). This interpretation is a novel hybrid between the classical definitions of the concept of sector (regulation theory, economic geography), the analytical framework of US urban political economy, an approach adopted by some French political scientists towards the "sectorization" and "territorialization" processes that affect public policies and eventually the concept of "collaborative planning" (Healey, 1997). Urban development projects involve complex relationships between those in charge of spatial planning and land development and stakeholders from the sectors that drive the local economy. This relationship between sectors and territories takes form around specific projects that are located within cities and plays a part in modifying urban forms. This link between the stakeholder interactions and urban form provides the framework for a geographical interpretation of governance. In Part 2 we will apply this interpretation framework to two river city configurations. Analyzing the relationship between the city, the river and the port in Venlo (the Netherlands) and Strasbourg (France) provides examples of project-based urban planning that is founded on negotiation between the river sector stakeholders (port authorities, waterway managers, transport and logistics firms), the territory's institutional stakeholders (the different levels of local and regional government) and the stakeholders involved in planning and land development (planning firms and bodies, property developers and investors). Venlo and Strasbourg illustrate this. Following a geographical interpretation of these two comparative examples, Part 3 will conclude by considering the forms taken by the above sector-territory dialogue within the urban space, the tools it uses and the levels at which it takes place.

\section{The geography of governance through the interplay between sectors and territories}

The concept of governance was developed so that the analysis of public policy was no longer restricted to governments (Le Galès, 2002). The governments alone are not responsible for the production of public policy: this also involves the participation of many stakeholders from outside the sphere of government, in particular from the private sector. The advocates of this concept present it as an area of research that sets out to explain the diversity of the relationships that are at work between the various stakeholders involved in public policies. It is therefore quite natural that this broad area of research involves several different approaches. In order to construct our interpretation framework we shall refer essentially to three of these: US urban political economy, in particular the approach that involves Urban Regimes, the French Regulation School and its definition of sectors and, finally, a strand of French political science that analyses public policies in terms of the interplay between sectors and territories. Eventually, we propose to analyze the urban governance as an interplay between sectors and territories / dialogue based on the concept of "collaborative planning" (Healey, 1997).

Beyond the public-private sector duality 
The theory of urban regimes provides a valid approach for dealing with the question of long-term informal coalitions between public and private sector stakeholders in the context of urban governance (Logan \& Molotch, 1987, Stone, 1989). In the American urban context the structural interdependence between local government and the local economic fabric leads to the development long-term "horizontal" coalitions between the two (Stone, 1993). Apart from the widely discussed issue of transposing this theory in order to analyse the somewhat different Europe urban contexts (Harding, 1997), there are two major problems with this approach (Mossberger \& Stoker, 2001). First, it focuses exclusively on the urban, or even the municipal, level, and does not easily take account of other levels and the stakeholders associated with them, that is to say possible "vertical" dimensions of governance. Second, it tends to perceive the private sector and the public sector as homogeneous entities. However, as a result of the heterogeneous nature of each of them, the public-private dichotomy is not perhaps the only way of explaining the interplay between stakeholders. Finally, the urban regimes approach allows us to grasp the horizontal dimension of urban governance, i.e. the links that exist between different local stakeholders. Nevertheless, it also needs to take account of the more vertical dimensions of governance, namely the ties which are formed between local stakeholders and other stakeholders who are connected with other levels of public policy and other levels of the economic system.

The Regulation School adopts a macroeconomic approach in order to understand the embeddedness of economic mechanisms (accumulation regime) within the regulation provided by the public sector and political regulation (which constitutes part of a mode of regulation) (Aglietta, 1976, Boyer \& Saillard 2002), mainly at the Nation State level. This embeddedness takes very different forms in different "sectors". A "sector" is defined as a complex social configuration of a historically identifiable sphere of production that is characterized by specific technologies and a specific workforce and within which firms are in competition on a national or international market (du Tertre, 2002). The properties of the sector create a regulation environment that is specific to it (Hollingsworth et al, 1994). Firms and workers form associations (unions that are specific to their branch of activity, employers' federations) and in this way lobby governments. National governments, or in some cases sub-national or supra-national governments, put in place policies for the sector which constitute a mode of regulation that is specific to it and which is characterized thus by its verticality. The different elements in this theory thus provide a way of perceiving the mechanisms of governance that are exerted on different economic sectors in a vertical, i.e. multi-level, way. The sector approach has been applied to the study of seaport evolution by W. Jacobs (2007) through the concept of "structure of provision" (Ball, 1986) which enables him to analyse the system formed by the port physical infrastructure, the institutional arrangements linked and the governance structure of the port.

A strand of French political science also views public policies with reference to the relationship between sectors and territories or, more exactly, to the processes of "sectorization" and "territorialization" at stakes within current public actions. In this approach, a sector corresponds to "a concrete subsystem with specific strategies and modes of action" ${ }^{3}$ (Baronne, 2008, p. 255), hence a set of actors that generate specific norms, rules, and paradigms that make it possible to govern a particular domain (transport, housing,

\footnotetext{
${ }^{3}$ Original in French. Translation : the authors.
} 
industry...). Consequently, they "express specific interests"4. The form taken by a sector of public policy, that is to say the sectorization process, is thus the result of "the perception of the problem and its solutions that belongs to the actors that dominate the sector" and it is therefore the outcome of the "division of labour"6 within public administrations (Muller, 2010, p. 595-596). The analysis of public policy through territorialization consists on the one hand of "examining (...) how issues are identified at a local level and then placed on the government (or European) agenda, and, on the other hand, taking account of subnational governments which produce their own paradigms and overall vision of the common good" 7 (Faure, 2010, p. 626). In other terms, the territorialization of public policy involves both the participation of subnational actors, from the public or private sectors, in the formation of national and European public policies, and the development and implementation of public policies that are specifically tailored for subnational levels. Understanding how public policy is produced therefore involves analyzing the links and power struggles that exist between these sectoral regulation processes and the cross-cutting policies that are supported by local policies (Halpern, 2007).

Finally, we propose to use this framework to move from the analysis of the production of public policy to the analysis of the way public policy produces the city. The dialectic that exists between the sectorization and territorialization of public policy allows us to conduct a systemic analysis of the links between territorial governance, which corresponds mainly to horizontal forms, and sectorial governance, which corresponds mainly to multi-level vertical forms.

Using the sector-territory relationship to analyze the production of cities: a proposed geographical interpretation framework

This rapid survey of the three approaches to governance confirms the need to look in greater depth at the interplay between the public and private sectors in order to observe the interplay between the different stakeholders. Dissociating sectors and territories may provide a way of doing this. In our attempt to develop a geographical approach towards governance, we shall therefore propose a straightforward definition of the term sector that is based on the work presented above. On the basis of regulation theory, we can define a sector simply as a set of public and private stakeholders that regulate and operate a specific area of the economy. With regard to the organization of ports and waterways, the sector thus consists not only of the firms that operate the ports (logistics firms, transport undertakings, freight handlers...) but also of the entities that manage the public port and waterways infrastructure (port authorities, waterways managers...). A sector of the economy is thus managed by both public and private stakeholders. In addition, a number of national and European regulatory measures apply to the port and river sector. There is therefore specific public regulation of the port and river sector which is produced by regulatory measures and public agencies. The public action that corresponds to this regulation is marked by its vertical nature and its relative independence from political arenas.

\footnotetext{
${ }^{4}$ Original in French. Translation : the authors.

${ }^{5}$ Original in French. Translation : the authors.

${ }^{6}$ Original in French. Translation : the authors.

${ }^{7}$ Original in French. Translation : the authors.
} 
In addition to this regulation of the sector, the sector is also embedded within a system of links with the different levels of public action: the municipality, inter-municipal authorities and the regions. We propose to use the terminology adopted by the school of political science mentioned above and refer to these levels as "territories". The "territories" of public action involve local levels of government, as opposed to the national and European levels. This public action is characterized by horizontal dynamics that involve mobilizing local stakeholders and the creation of coalitions and conflict between them, which transcend the boundaries of the sectoral public policies conducted by States and the European Union. State agencies may however take part in these horizontal territorial dynamics. Defining the stakeholders that are present in the territories remains an open issue, but it is important to establish at the outset that not only public institutions are involved.

Figure 1: the sector / territory dialogues

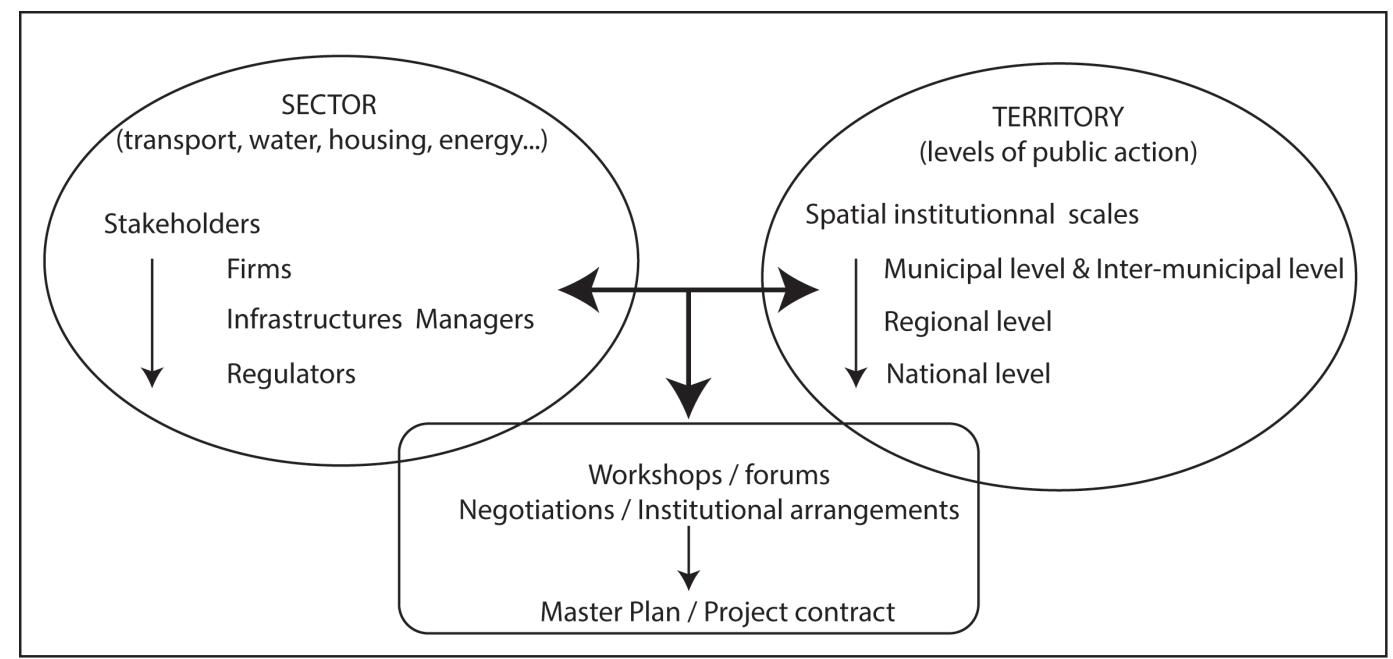

Source: own compilation

Thus, our sector-territory interpretation framework allows us to examine what the impacts of the sector-territory dialogue are on the mechanisms that produce the city therefore on urban geography. This dialogue take the form of institutional arrangements, workshops, forums, shared discourses, negotiations, which echoes the advent of "collaborative planning" (Healey, 1997) as main paradigm in urban affairs. Our argument is that the form taken by sector-territory interplay has a considerable impact on which stakeholders play a part in production of the city. The scientific issue is therefore not so much to determine which stakeholders belong to the territory and which to the sector but more to understand the processes of territorialization and sectorization that take place during dialogue between the two groups of stakeholders. These processes define the type of urban governance which results from interactions that we will study in the case of two inland port cities.

\section{Materials. A comparative application, the case of urban port projects (Strasbourg-Venlo)}


We shall now apply this interpretation framework to some urban projects that are located in river cities; and more particularly those that involve the relationship between the city, the river and the port. There is an abundant literature, particularly in geography, on the last of these. This academic research deals mainly with maritime seaports, frequently major European and North American metropolises (Bird, 1963, Hoyle et Pinder, 1992, Brown, 2009, Hein 2011, Wiegmans \& Louw 2011). It not only covers a wide range of cases but allows us to identify a temporal change in the city-port relationship that also applies to river ports. This change involves a process of connection and disconnection (Hall, 2010).

The original link that existed between the city and its port has gradually loosened. The processes of industrial expansion, port specialization and the consolidation of flows are disconnecting cities from their ports. The extension of port activities outside the city rapidly creates a problem of derelict land in urban centres. Such derelict land constitutes a reserve of land which becomes a subject of dialogue between port managers and the urban public authorities. In many cities this dialogue leads to the creation of major urban projects. These projects are based on a process of "docklandization", by which we mean the promotion of urban functions (housing, recreation, tourism) which conflict with port activity other than pleasure boating (Charlier, 1994, Norcliffe et al., 1996). The development of maritime and river cities is therefore organized around the extension of major port facilities outside the city and the redevelopment of derelict land in the centre (Ducruet, 2007).

This change is well-known and has been studied in detail. However, a new phase is taking shape. This has its origin in the attempt in many river and port cities to reconnect the city and the port. This new phase is the outcome of two processes. First, urban extension is gradually reaching the port facilities thereby creating new interfaces. Extension of this type means that the relationship between port areas and urban areas must be renegotiated in a context where the amount of available land is falling. This phase is also driven by the adoption of new development goals for urban policy. The introduction of the paradigms of sustainable development in metropolises and current concerns over jobs and growth in the present crisis is tending to reframe the relationship between the port and the city. Understanding these new relationships between port authorities, institutions and economic stakeholders is currently a new research agenda on port city interfaces in Europe (Daamen \& Vries, 2013) and in North America (Brown \& Hall, 2014). It is this relationship between the port and the city and the dialogues between stakeholders that it generates that we wish to examine by applying our sector-territory interpretation framework to two river cities.

Case study 1. Strasbourg: a river city in a transborder location (port and production of the city)

The trajectory of the river city

The urban trajectory of the port city of Strasbourg has been made more complex the fact that its river is on a border (Beyer \& Debrie, 2011). This means it is possible to interpret this trajectory on the basis of Hall's threefold process of connection, disconnection and reconnection. The first phase (connection) led to the installation of urban quays around the historic centre of the city. The military role of the city and the hydrological constraints affecting the Rhine confined the port to the area within the city walls. The second phase (disconnection) was the outcome of the dissociation between port functions and urban 
functions that was made possible by the transfer of port infrastructure to the Rhine. The city's function as a hub on the Rhine was strengthened when it became part of the German Empire, and then further accentuated when the Alsace region was returned to France (1919) when the port of Strasbourg became a strategic interface between Germany and the industrial and agricultural hinterland of the East of France. The form of the city was established at this time. It was based on a separation, which still exists, between the West of the city (urban functions) and the East of the city (industrial and port functions) which borders on the Rhine. The Franco-German border heightens this separation as it means the port is in a doubly peripheral position, on the outskirts of the conurbation and adjacent to the Rhine on the edge of the national territory. In Strasbourg, the conurbation is bounded more by the port than the Rhine. The third phase (reconnection) is taking place at the moment. It is very much linked to the project to consolidate a crossborder conurbation (the Strasbourg-Kehl ecocity) which places the port area at the centre of an urban development project. Reconnection therefore has two very different aspects, the redevelopment of port land in the city centre for new urban uses (housing, offices, recreation) along the East-West line followed by the transborder project, and fitting the port into the development goals identified in planning documents (Intermunicipal Masterplan 2030) The reconnection in Strasbourg goes hand-inhand with the territorialization of port management.

Map 1: The location of port land and urban land 


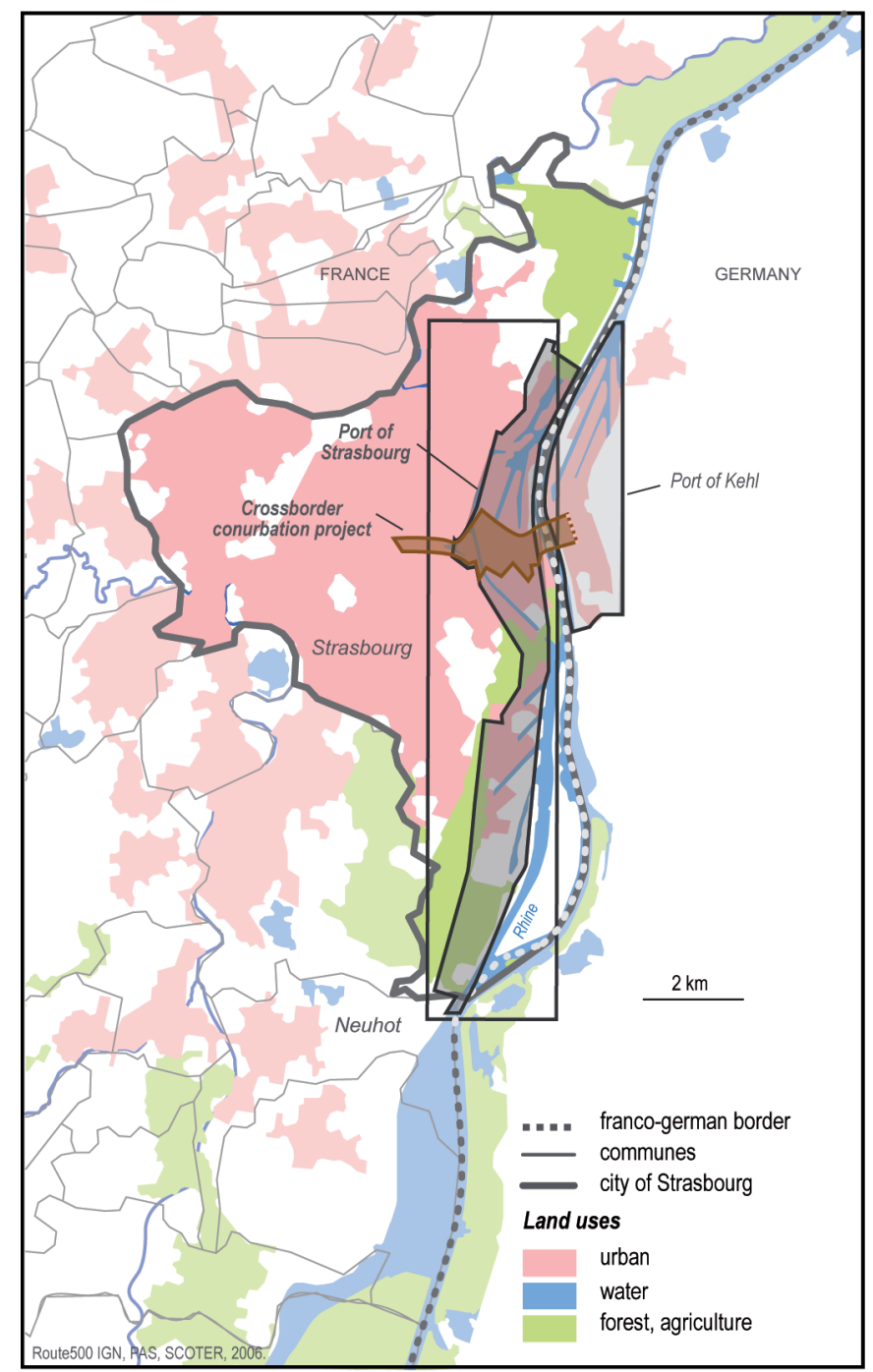

Source: Debrie, 2013

Urban projects: a dialogue between the sector and the territory

The transborder project that has the backing of the current municipality sets up a process of negotiation between the stakeholders from the port sector and those from the urban public action and land development sector. The port authority, which has responsibility for the public land on the river, has recently adopted a property development strategy in those parts of its land that are affected by the transborder city project. The port gradually started to use the term "derelict land", which had been taboo for so long. This change led to the port authority assuming a new position, cofinancing (with the Urban Community of Strasbourg) the calls for architectural projects in the land between the port and the city and taking part in various urban workshops. In the strategic project for the port (Strasbourg-2020), the need for involvement in property development was identified for two projects in particular (Starlette and Citadelle). For these two projects, the port acts as an urban property developer in the areas in question for projects that combine tertiary sector activities and housing. This radical change of behaviour in a context where urban pressure is high means that it will also be necessary to purchase land for industrial and port use outside the city. This increase in port, 
industrial and logistics capacities is supported by the General Council of Bas Rhin (the Département) and the Regional Council of Alsace (the Region) ${ }^{8}$. The position of the stakeholders of the Urban Community was influenced by this period of negotiations that has taken place in the framework of a development contract that brings together the port authority, the city of Strasbourg and the intermunicipal authority. This contract confirms the recognition of the importance of the port for the urban economy that was stated in the Strasbourg Regional Masterplan. In addition to this port-city dialogue, it was decided to hold a number of port workshops which were open to the public. These workshops have allowed a number of contradictory views to be expressed about the nature of the city-port relationship. Functional diversity was advocated by the residents and architects and urban planners who formed a co-operative in order to project a specific image of the city. This vision was opposed to the industrial future advocated by the port users who formed a "Port Users Group" (GUP) under the aegis of the Chamber of Commerce and Industry. Negotiation between the city and port in Strasbourg was therefore characterized by a dialogue between the Urban Community and the Port Authority in which the stakeholders belonging to civil society, associations and the industries present in the port met during workshops. The discussions revealed tensions between the recognition of the port's strategic role and residential and environmental pressures. During the negotiations, the discussion groups gradually became better organized. Environmental associations and the advocates of port urbanization played an active part in the debates, frequently expressing well organized views. With regard to industrial aspects, the firms in the port area have come together more recently in order to present a "wish list" which sets out to defend the interests of the port. The discourse of the industrial stakeholders was above all based on the demand for clarity over a twenty year time horizon for the port area which is coming under increasing pressure from access changes and the urban redevelopment of former industrial land.

Thus, two principal processes seem to emerge from this dialogue: the creation of an urban project for a transborder metropolis running East-West and the consolidation of a specific economic port model which takes account of this change in the city. The urban planning projects lie along an axis which runs from Strasbourg to Kehl and passes through the port area. The port of Strasbourg has taken account of this urban pressure by integrating it within its economic model, i.e. by acting as a property developer. It manages the property transactions directly and attempts to retain ownership of property which it rents out in order to obtain lasting resources. At the same time that parts of the central port zone are undergoing redevelopment, the port authority is purchasing new land outside the city to add to the port area. In this connection, the General Council of the Département, which under the system that operates in Alsace is responsible for indirect aid and subsidies for firms, and the Regional Council in the framework of the project contract have supported the port projects by helping to finance infrastructure and facilities. The port authority is thus involved in negotiation with the city which enables it to expand, by acting in partnership with the other local and regional authorities, and negotiate the improvement of its accessibility which is under pressure from urban projects. This change tends to confirm the existence of a process of territorialisation, which means that the question of the port is increasingly present in the planning activities of the local government.

\footnotetext{
${ }^{8}$ Decentralization in France, which began in the early 1980s, is based on the distribution of powers between Regions (Regional Council), Départements (General Council), inter-municipal authorities and municipalities. Recent developments are tending to strengthen the powers of the inter-municipal level which is perceived as the appropriate level for metropolitan development.
} 
Figure 2: The sector-territory dialogue: the example of the Strasbourg transborder metropolis

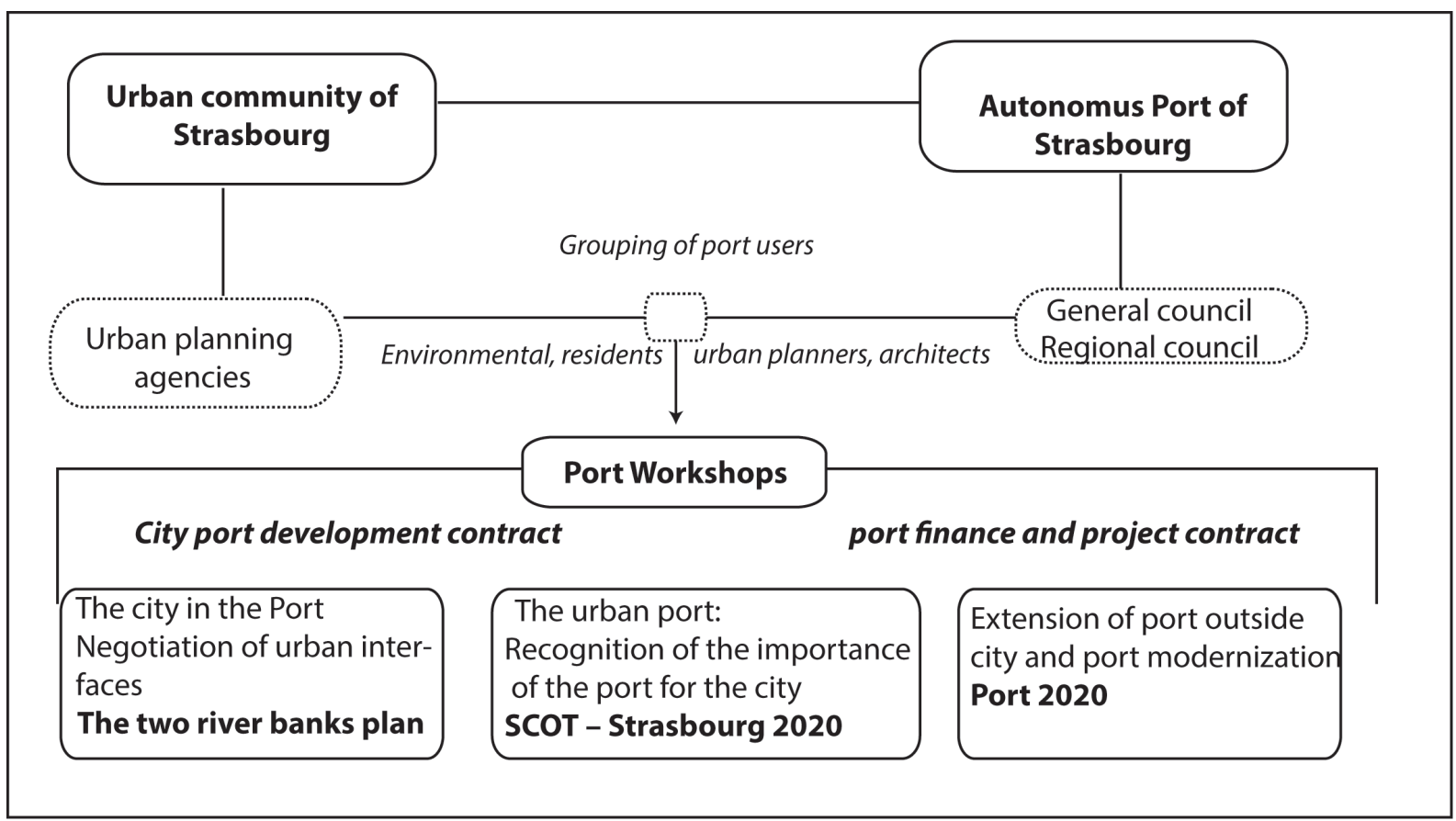

Source: own compilation

Case study 2. Venlo: when a city creates a port.

Venlo is located on the Eastern border of the Netherlands, on the doorstep of the Ruhr conurbation in Germany and about $150 \mathrm{~km}$ from the outskirts of Rotterdam and Antwerp. Historically, it has never been an important river city, unlike Strasbourg. The role of its port remained negligible for a long time. However, it is now benefiting from the development of logistics in Venlo, which has become on of the country's largest logistics centres. The sectorterritory dialogue that is responsible for the port's trajectory can be broken down into two stages. The first consists of the creation of a local coalition involving the municipality and the region's logistics firms. This coalition still has a central position in the dialogue concerning Venlo. The second stage focus around the "Venlo Greenport" project for the territory, which changed the issues, goals and tools employed in the dialogue between the port and logistics sector and the territory (Raimbault et al., 2015).

A logistics growth coalition that discovers the river

The development of Venlo as a port and for logistics was, initially, due to a dialogue between the logistics and port sector, which is represented locally by the regional firms that are located in Venlo, and the municipality. Local governance was thus the outcome of horizontal interaction between these firms and local government, therefore territorial interactions and mechanisms. This means the urban regimes approach provides an interesting interpretation framework that helps us identify the mechanisms of governance. The coalition was particularly interested in accommodating local logistical interests with regard to the design of port areas but also wished to support the competitiveness of firms by means of a promotion and innovation programme. 
In the western part of the city, the municipality built a number of port and logistics zones known as Venlo Trade Port. This covered a total surface area of 1400 ha and was gradually provided with rail and river container terminals. Venlo city council thus acquired the facilities and institutional tools of a port authority. This provided it with rent and port dues which enabled it to finance other policies. At the same time, the local logistics firms formed several associations in order to present the views of the logistics community to the city council. Their dialogue with local government was primarily focused on the logistics promotion and innovation programmes known as "Viaport Venlo". While this was financed by the municipality, the programme's agenda was set by the participating firms. It institutionalized the participation of firms in local policies to do with logistical interests. Logistics thus became a formalized concern within the municipal administrative apparatus. It became sectorized (Muller, 2010) and part of the municipal administration. Some civil servants of the municipality are dedicated solely to logistics, and key politicians and civil servants work or have worked in the logistics sector. Finally, Venlo seems to be a case of an urban regime that consists of a logistics "growth coalition" (Logan, Molotch, 1987), i.e. a more or less informal alliance between local government and local logistics firms which set out to achieve local logistical development. More precisely, its goal was to make the firms located at Venlo competitive on the European market.

\section{Greenport Venlo: a new sector-territory dialogue}

The "greenport" is a recent concept in Dutch national economic and spatial planning policy. Its aim is to promote the development of horticultural clusters in which agricultural and industrial production are grouped together with logistics services for exporting the products. They are one of the three types of economic cluster promoted by national planning since 2004. When it became a "greenport", the economic importance of Venlo received national recognition for the first time. However, Venlo has never regarded horticulture as an important sector, its stated aim has always been to be a port hub. The new political and institutional context that has been opened up by "greenports" provided a window of opportunity that allowed the coalition to relaunch the growth machine by tapping into new resources from outside the local level. The logistics regime of Venlo has managed to adapt the national "greenport" framework to its logistics projects. It has redefined the goals by involving stakeholders and sectors from outside horticulture. In other terms, it has "territorialized" the "greenport" (Faure, 2010) to serve its logistical interests. Consequently, the sector-territory dialogue has been turned upside down.

The goal has changed. It has ceased to be focused on creating the conditions for the local logistics firms to be competitive and is now more concerned with implementing the major territorial project that constitutes Greenport Venlo. The Greenport means that projectbased governance applies in Venlo. The project mainly consists of a very large programme to improve 5000 hectares of land, including 2000 hectares of new logistics and port areas that extend Venlo Trade Port, in the west of Venlo. A new institution, known as the Greenport Venlo Foundation (fig. 3), is in charge of the project both politically and operationally. As this has the status of a foundation, it operates under private law and is thus subject to many fewer constraints than a municipal administrative department. The governance arrangements created by the Greenport framework allowed local stakeholders to remove municipal political constraints with regard to economic and land development policies, the municipalities of the urban area (Regio Venlo), the province and the local employers' associations sit on its board. 
The comprehensive nature of the project means that the Greenport Venlo Foundation implements most local economic policies, such as the subsidies for companies locating to the area, which was previously directly controlled by the city council. Public-private governance has also been institutionalized. A new local publicly owned company, the Development Company Greenport Venlo (DCGV) has been set up to take charge of land development. This too operates under private law. The fact that it not only has a very ambitious development programme (the project has an estimated budget of $€ 743$ million $^{9}$ ) but also a specially formed company to implement it is unique for a "greenport". It is the outcome of the territorialization of the project. The creation of this publicly owned company represents a profound break with the past in that, in the Netherlands, lucrative planning policies are traditionally strictly municipal and implemented by a municipal bureau. The development of port and logistical spaces has thus ceased to be the preserve of traditional local policies.

Map 2: The Venlo Tradeports within the urban area

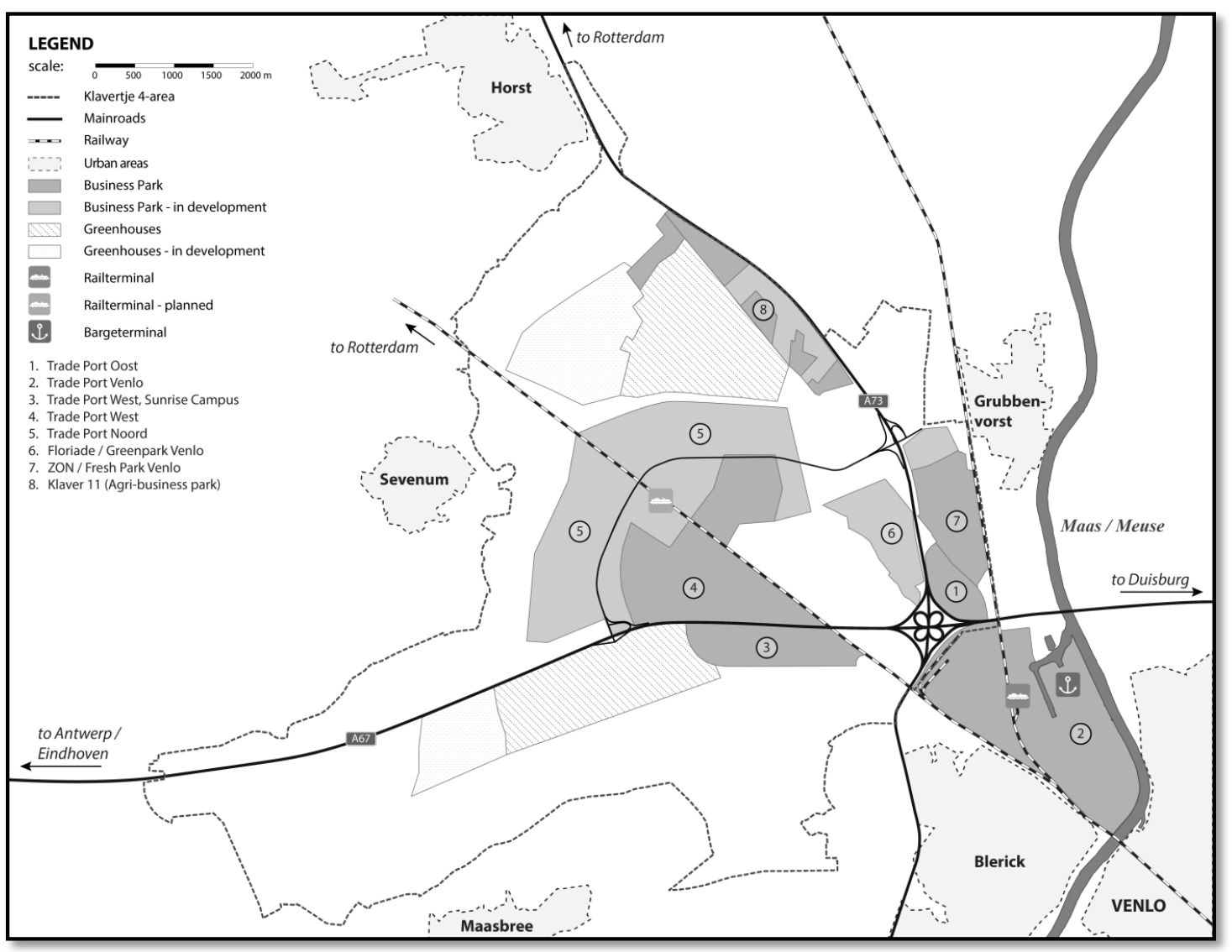

Source: Raimbault et al., 2015.

The institutions that were set up during the creation of the "greenport" have thus made it possible to free local economic policies from the constraints of municipal policies. Particularly important is the emergence of new ways of governing development and logistics property. These are becoming sectorized via an autonomous publicly-owned local company, at a time

\footnotetext{
${ }^{9}$ Greenport Venlo Masterplan, 2009
} 
when the availability of property has become an extremely important factor for attracting international logistics companies (Hesse, 2004, Raimbault, 2013a, 2013b). The major international property developers and investors chose Venlo at the turn of the 21 st century and continue to invest in it. The "greenport" makes it possible to form a coalition with these firms that do not belong to the historical coalition we have described above. In addition, logistics property companies are very much in favor of the new organization of local institutions which allows them to work with property professionals, the DCGV, rather than a municipal office. This coalition is able to attract the largest logistics firms by "selling" Venlo internationally. The goals of the first and second stages are therefore different. In the case of the "greenport" project and tools, the strategy is more and more clearly aimed at international property investors. The goal has ceased to be to ensure that the local firms are competitive and is now to attract international companies. These two types of firms express different demands vis-à-vis the municipality of Venlo.

Finally the novel dialogue between the sector and the territory at Venlo, which is characterized by ties which are almost exclusively horizontal, has been quite profoundly altered as a result of changes in a number of sectors. First, national horticultural policy combined with national spatial planning policy has promoted Venlo to the status of a "greenport". By territorializing this national policy, Venlo has redefined the local logistics sector and municipal economic and development policies. These are no longer merely municipal policies but have become the policies of a public-private foundation and a publiclyowned company, both of which bring together additional territorial levels. At the same time, changes in the logistics sector, which give a greater role to international firms and global property firms, have encouraged the goal of becoming more attractive by offering land and property besides the goal of increasing the competitiveness of the historical local firms. The dialogue has thus opened out to include new players who are active on the national and international levels. It is particularly focused on the creation of large business zones to the west of the city. What we are witnessing in Venlo is therefore a strong dynamic of spatial and institutional disconnection of the production of logistics and port spaces after an initial period when such production tended to be integrated with the city and its municipal institutions. So, paradoxically, the process by which the national Greenport policy has been territorialized in Venlo has provided the opportunity to depoliticize port and logistics development. Consequently, these local policies have been sectorized within the bodies of local governance. More precisely, Venlo shows that the production of port and logistics spaces can become a sector that is disconnected from the rest of production of the city. A general trend towards territorialisation does not therefore prevent the formation of dynamics of sectorization and disconnection. In Venlo, the reconnection of the port and the city is not on the local political agenda.

Figure 3: The sector-territory dialogue: the example of Greenport Venlo 


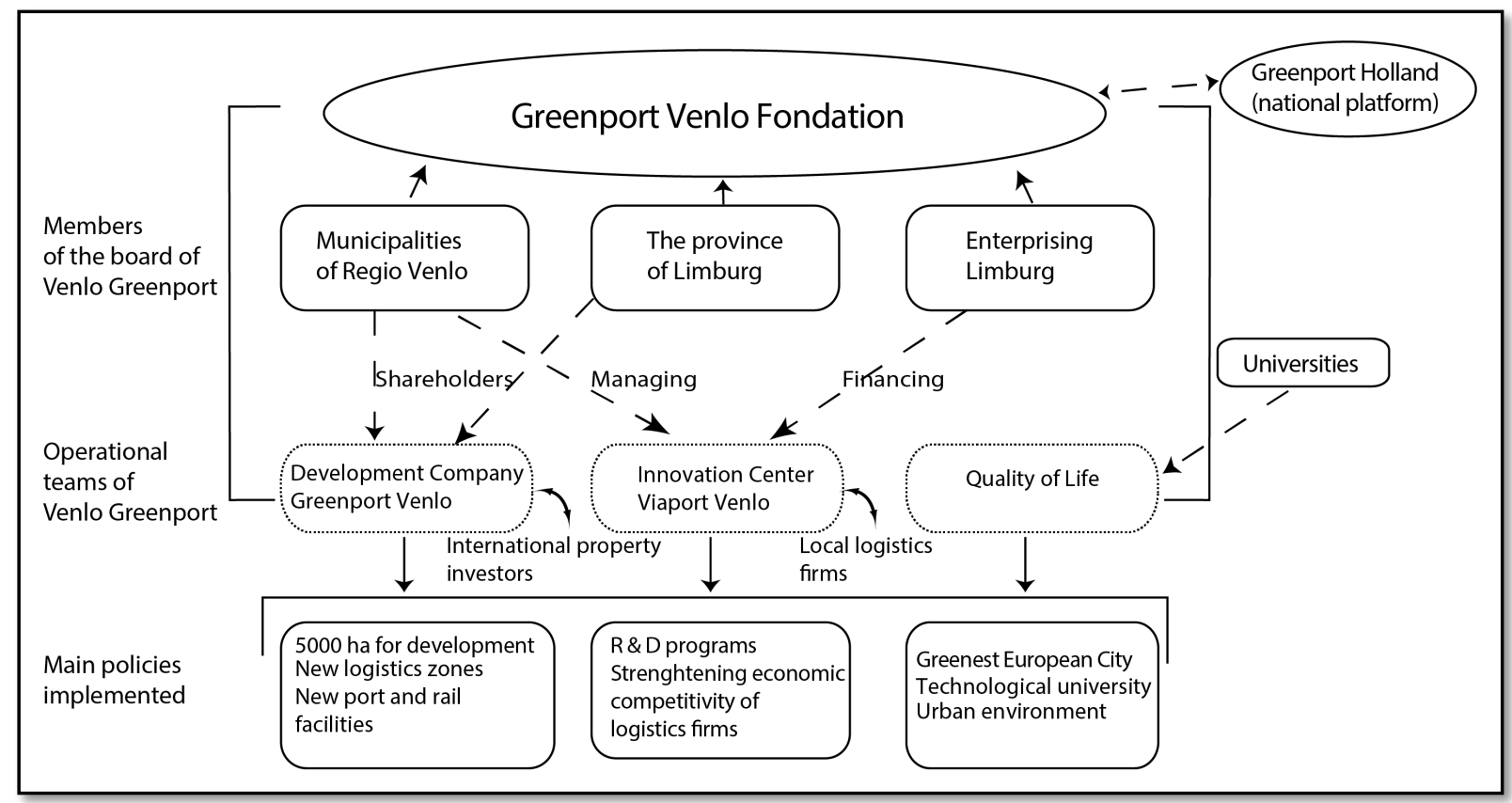

Source: own compilation from Raimbault et al, 2015.

\section{Results/discussion: the different forms of dialogue and their impact on production of the city}

Our analysis of two river cities has provided the opportunity to apply a specific geographical interpretation framework to urban governance. Both the classical instruments of urban planning and new contractual tools were employed in the two cases we have studied and our work allows us to explain the types of linkage that exist between economic sectors and the territories within which public action takes place. The city-inland-port relationship thus generates a specific and evolving form of governance that involves the national, regional and urban levels of government and the port and logistics sector.

In Strasbourg, governance is currently centred around a dialogue between the urban community and the port authority. Both port companies and the local population are able to contribute to this dialogue, whose aim is to achieve the two shared goals of changing the nature of city-port interfaces and maintaining activity at the port. In Venlo, the transition from a public-private municipal coalition to more forceful national intervention and above all the setting up of new institutional structures that step outside the traditional framework of municipal planning illustrate the evolving nature of this type of governance. Nevertheless, this transition allows us to gauge the importance of the port in the context of the city's economic project. The two case studies illustrate the link between governance and changing urban forms.

The changes in the urban geography of Strasbourg are also linked to the changes in the city-port interfaces we have just mentioned. The changes have removed the historical division of the city and allowed urban projects to extend eastwards with a view to the creation of a transborder metropolis. Negotiations between the port authorities and the urban communities (dealing with the transformation of interfaces and extension outside the city) are gradually tending to modify the key elements of urban space. But to understand this new 
geography, we need to go beyond urban governance in the strict sense of the term and analyse the role played by regional and national levels of government in the development of the port area. The city-port relationship therefore plays a part in modifications that occur at the metropolitan level, modifying historical interfaces in urban centres, developing peripheral business zones and consolidating a regional system of ports.

The changes that have taken place in the urban geography of Venlo are also linked to the nature of the dialogue between the sectors present in the port and urban territories. The city has chosen a different path from Strasbourg and the economic project that has been approved by its council tends to deepen the institutional, functional and spatial dissociation between the ports and the urban areas in order to favour the development of logistics zones to the west of the city. The two logistics coalitions have each in turn been responsible for considerable development of the logistics zones without changing the morphology of the urban centre. The nature of production of the city underwent a change. During the phase that we have termed the logistics growth coalition, the production logistics and port spaces in Venlo was due to the territory and a structured local logistics sector. The real estate industry was only marginally involved in this dialogue. With the Greenport Venlo project, the production of logistics spaces was put in the hands of institutions that were fairly disconnected from the municipality and local firms. The existence of large reserves of land to the west of Venlo was a decisive factor for the adoption of this policy. This land meant that the Greenport project could be implemented as part of a major development project, which required the creation of new institutions.

These two case studies thus allow us to understand better the links between production of the city and the sector-territory dialogue. First, urban form reveals the dialogues that take place in the framework of urban governance and is a decisive contextual factor that determines the issues and how these are perceived by local stakeholders. Next, the public policy goals that result from the dialogue should not be forgotten. A different type of space is produced if the goal is to make regional firms competitive or if it is to attract international logistics investors. The difference is even greater if the goal is to develop the port or to construct an urban link across an international border. At the same time the public policy tools that are created for and by the dialogue also have major impacts on the way the production of the city takes place. Strasbourg provides an example of dialogue which is based both on conventional administrative documents and the use of new contractual tools. Such tools, which are peculiar to project-based governance change the stakeholders, goals and the levels of government associated with local port management. In the case of Venlo, we have highlighted the importance of the institutional transformations which have radically modified the sector-territory dialogue and led to the creation of port and logistics zones covering some 5000 ha. These mechanisms, which have fostered either the territorialisation or the sectorization of the production of the city, have placed sector-territory dialogues at the centre of the creation of metropolitan areas at all levels.

The literature on urban governance has been marked by certain currents of political science and institutional economics. In the large body of research dealing with governance, the study of the links between the economic sectors and the different levels of public action are given central importance, providing a way of analysing the complex interplay between the different stakeholders. But these approaches frequently pay little attention to the geographical consequences of this interplay. The aim of this paper was to apply a sector- 
territory interpretation framework to two river cities in order to understand how the interplay between the stakeholders modifies urban geography. Thus, this study demonstrates the value of a geographical approach to governance, i.e. an analysis of the link between stakeholder interplay and changes in urban form and the different levels of urban government.

\section{Acknowledgements}

This paper was made possible by generous funding from the National Research Agency of France (Work program «Sustainable cities », project FLUIDE : http://fluide.ifsttar.fr) and the French coordination program for land transport, Research and Innovation (PREDIT, http://www.predit.prd.fr/predit4/english, project PLEIADE).

\section{References}

Aglietta, M (1976) Régulation et crises du capitalisme, Calmann-Lévy, Paris.

Ball, M (1986) The built environment and the urban question. Environment and Planning D: Society and Space, 4, 447-464.

Barone, S (2008) Le train des Régions. Régionalisation des transports collectifs et recompositions de l'action publique, Thèse de Doctorat en Sciences Politiques, Université Montpellier 1, Faculté de droit.

Benko, G and Dunford, M (dir.) (1991) Industrial Change and Regional Development: The Transformation of New Industrial Spaces, London, Belhaven Press-Pinter.

Beyer, A and Debrie, J (2011) Les temporalités urbaines et frontalières du port de Strasbourg : analyse géo-historique d'une relation fluviale ville-port. Revue Métropoles, $n^{\circ} 10$. (http://metropoles.revues.org/).

Bird, J (1963) The major seaports of the United Kingdom, Hutchinson, London.

Charlier, J (1994) Anvers et le syndrome des docklands. Acta Geographica Lovaniensa, 34, 311-319.

Brenner, N and Theodore, N (2002) Cities and the geographies of 'actually existing neoliberalism'. Antipode, 34, 349-379.

Brown, P (2009) America's Waterfront Revival, Philadelphia, University of Pennsylvania Press.

Brown, P and Hall, P (2014) Ports and Waterfronts. In Elmer, V and Leigland, A, Infrastructure Planning and Finance : a Smart and Sustainable Guide, Abingdon, Routledge.

Boyer, R and Saillard, Y (Ed.) (2002) Regulation Theory. The State of the Art, Routledge, London \& New-York.

Daamen, T and Vries, I (2013) Governing the European port-city interface: institutionnal impacts on spatial projects between city and port. Journal of Transport Geography, vol 27, 413.

Douglass, M. and Huang, L (2007) Globalizing the city in southeast Asia: utopia on the urban edge the case of Phu My Hung. International Journal of Asia-Pacific Studies, 3, 1-42. 
Ducruet, C (2007) A metageography of port-city relationships. In : Wang, J.J et al. (eds.), Ports, Cities, and Global Supply Chains, Ashgate, Aldershot, 157-172.

Fainstein, S (2004) The City Builders: Property, Politics and Planning in London and New York, Oxford: Blackwell.

Faure, A (2010) Territoires/Territorialisation. In Boussaguet and al. Dictionnaire des politiques publiques, 623-632. Paris: Presses de Sciences-Po.

Graham, S and Marvin, S (2001) Splintering Urbanism: Networked Infrastructures, Technological Mobilities and the Urban Condition. Oxford: Blackwell.

Hall, P (2010) Maritime ports and the politics of reconnection. In Desfor, $G$ and al, Transforming Urban Waterfronts: Fixity and Flow, Abingdon, Routledge, 17-34.

Halpern, C (2007) Extension des aéroports : I'action publique entre secteur et territoire. In Faure, $\mathrm{A}$ and Négrier, $\mathrm{E}$ (dir.), Les politiques publiques à l'épreuve de l'action locale, Paris, L'harmattan, 87-92.

Harding, A (1997) Urban Regimes in a Europe of the Cities?. European Urban and Regional Studies, 4: 291, 291-314.

Harvey, D (1989) From managerialism to entrepreneurialism: the transformation of urban governance in late capitalism. Geografiska Annaler, 71B, 3-17.

Healey, P (1997) Collaborative Planning, Shaping Places in Fragmented Societies, Vancouver, University of British Columbia Press.

Hein, C (2011) Port Cities. Dynamic Landscapes and Global Networks, London, Routledge.

Hoyle, B.S and Pinder, D (1992) European Port Cities in transition, Belhaven Press, London.

Jacobs, W (2007) Political economy of port competition. Institutional analysis from Rotterdam, Southern California and Dubai. Nijmegen: Academic Press Europe.

Le Galès, P (2002) Regulations and Governance in European Cities. International Journal of urban and Regional Research, vol 22, Issue 3, 482-506.

Macleod, G (2011) Urban politics reconsidered. Growth machine to post-democratic city? Urban Studies 48 (12), 2629-2660.

McKenzie, E (2006) The dynamics of privatopia: private residential governance in the USA. In Glasze, G and al. Private Cities, 9-30. London, Routledge.

Mossberger, K and Stoker, G (2001) The Evolution of Urban Regime theory. The Challenge of Conceptualization. Urban Affairs Review, vol. 36, $n^{\circ} 6,810-835$.

Muller, P (2010) Secteur. In Boussaguet, L ans al. Dictionnaire des politiques publiques, 591599. Paris, Presses de Sciences-Po.

Norcliffe, $G$ and al (1996) The emergence of postmodernism on the urban waterfront. Journal of Transport Geography, 4-2, 123-134.

Pecqueur, P (2006) Le tournant territorial de l'économie globale. Espaces et sociétés, $\mathrm{n}^{\circ} 124-125,2006 / 2-3$.

Pinson, G (2009) Gouverner la ville par projet. Urbanisme et gouvernance des villes européennes, Paris, Presses de Sciences Po.

Raimbault, $\mathrm{N}$ and al (2015) Port regionalization from a relational perspective. The rise of Venlo as Dutch international logistics hub. Tijdschrift voor economische en sociale geografie, published online.

Tertre, C (2002) Sector-based dimensions of regulation and the wage-labour nexus. In Boyer, R and al. Regulation theory. State of the art, 204-213, London, Routledge. 
Young, D and Keil, R (2010) Reconnecting the disconnected: the politics of infrastructure in the in-between city. Cities, 27, 87-95.

Wiegmans, B and Louw, E (2011) Changing Port City Relationships at Amsterdam: A New Phase in the Interface. Journal of Transport Geography 19, 575-583. 